\title{
Budidaya Jamur Tiram Di Desa Darek
}

\author{
Ali Imran, Supriadin, Nune Wire Panji Sakti, Syahrir \\ Universitas Pendidikan Mandalika \\ e-mail :aliimran@ikipmataram.ac.id
}

\begin{abstract}
Abstrak; Kegiatan pengabdian kepada masyarakat ini akan dilaksanakan di Desa Darek Kecamatan Praya Barat Daya Kabupaten Lombok Tengah. Pemilihan tempat pengabdian ini dilakukan berdasarkan potensi yang ada dan kondisi suhu serta kelembaban dilingkungan desa Darek sangat memadai dan mendukung untuk pembudidayaan jamur tiram. Selain itu, penduduk Desa tidak punya pekerjaan tetap sehingga sangat perlu untuk diberdayakan. Oleh karena itu, kegiatan pengabdian ini bertujuan untuk memberdayakan kelompok masyarakat yang tidak produktif menjadi masyarakat yang mandiri secara ekonomi. Kegiatan pengabdian ini akan sangat bermanfaat begi masyarakat Desa Darek, diantaranya: (1) membantu masyarakat untuk memiliki pengetahuan dan keterampilan yang dapat dikembangkan secara mandiri atau kelompok sebagai sistem mata pencaharian alternatif;(2) meningkatkan perekonomian masyarakat yang mandiri melalui pembudidayaan Jamur Tiram yang bernilai ekonomi; (3) menghasilkan bahan pangan berupa jamur tiram yang dapat dikonsumsi oleh masyarakat setempat maupun masyarakat lainnya. Oleh karena itu, program pengabdian ini sangat penting dilakukan. Dalam pelaksaannya, pengabdian kepada masyarakat ini akan menghasilkan luaran berupa: (1) menghasilkan bahan pangan berupa jamur tiram; dan (2) Laporan Pengabdian.
\end{abstract}

Kata Kunci: Budidaya, Jamur Tiram.

\section{PENDAHULUAN}

Desa Darekmerupakansalah suatu desa yang terletak di kecamatan Praya Barat Daya Lombok Tengah Nusa Tenggara Barat. Desa ini terdiri dari sebelas dusun dan sebagian besar masyarakatnyaberprofesi sebagai kuli bangunan, peternak dan petani.Beragamnya profesi masyarakat desa Darek menyebabkan banyaknya potensi yang dapat dikembangkan di desa ini. Tetapi pengetahuan masyarakat dalam memanfaatkan potensi tersebut masih kurang sehingga masyarakat tidak dapat mengembangkan usaha lain selain profesi yang mereka jalani.Seiring dengan perkembangan di segala bidang, menyebabkan bergesernyan lahan pencarian bagi masyarakat. Kurangnya skil yang dimiliki masyarakat mengakibatkan banyak masyarakat yang kehilangan pekerjaan, dengan demikian akan berdampak pada menurunnya tingkat perekonomian masyarakat.

Salah satu usaha yang dapat dikembangkan di desa Darek adalah budidaya jamur tiram.Berdasarkan hasil observasi keadaan desa, bahwa desa Darek bertemperature udara cukup dingin dan lembab.Kondisi ini tentunya cocok untuk membudidayakan jamur tiram.Dalam pembudidayaan jamurtiram ini, suhu udara disekitar memegang peranan yang sangat penting untuk mendapatkan pertumbuhan badan bibit yang optimum.Pembudidayaan jamur tiram tidak membutuhkan lahan yang terlalu luas serta perawatannya mudah dan tidak terlalu mahal.Hal yang lebih mendukung adalah bahan-bahan yang digunakan untuk pengembangan budidaya jamur ini sangat banyak tersedia di desa Darek, yaitu limbah serutan kayu atau serbuk kayu yang berasal dari tukang bangunan serta sekam padi yang berasal dari penggilingan padi yang saat ini hanya dimanfaatkan peternak untuk dijadikan dedak sebagai pakan ternak.selain itu,limbah jamur tiram dapat dimanfaatkan untuk membuat pupuk organik dengan mencampurnya limbah rumah tangga dan kotoran ternak dari para peternak sekitar yang selama ini tidak termanfaatkan. Selanjutnya pupuk organik dapat dimanfaatkan oleh para petani yang selama 
ini hanya mengandalkan pupuk kimia sebagai pupuk untuk pertanian mereka.

Berdasarkan analisis situasi di atas, kegiatan pengabdian ini menjadi solusi kebutuhan masyarakat desa Dasek dalam memecahkan masalah-masalah perekonomian dan ketahanan pangan setidaknya dengan jamur tiram sebagai media kegiatan produktif dapat membantu pemenuhan akan bahan makan yang dapat diolah sendiri bagi keluarga atau bahkan hasil budidaya jamur dapat dipasarkan karena akhir-akhir ini jamur menjadi bahan makanan yang cocok secara pemenuhan gisi bagi kelompok masyarakat tertentu atau usia-usia degeneratif atau lansia. Sehingga dengan adanya program ini akan menjadi prospek peningkatan penghasilan masyarakat khususnya di Desa Darek Lombok Tengah.

Yang menjadi mitra dalam kegiatan pengabdian pada masyarakat ini adalah mitra I adalah H.Ismail Sahabudin, S.IP (Kepala Desa) di Desa Darek Kecamatan Praya Barat Daya Lombok Tengah.

Masalah utama yang dihadapi oleh Masyarakat dari mitra tersebut adalah dapat diuraikan sebagai berikut:

1. Masyarakat tidak punya pekerjaan tetap

2. Perekonomian masyarakat adalah menengah ke bawah sehingga susah untuk membuat/mengembangkan usaha

3. Masih adanya warga masyarakat yang belum memiliki pengetahuan dan keterampilan tertentu guna mengisi kegiatan dalam kehidupan sehari-hari secara berkualitas.

4. Belum berkembangnya kemampuan wirausaha dalam melakukan peningkatan kualitas hidup bagi diri, keluarga dan masyarakat sekitarnya khususnya warga masyarakat yang tidak melakukan pekerjaan di luar rumah (misalnya ibu rumah tangga, pensiuan atau warga yang masih hidup dalam kemiskinan).

Oleh karena itu, keempat permasalahan tersebut tentunya dapat disolusikan dengan melakukan pengabdian kepada masyarakat "Pengembangan Budidaya Jamur Tiram" ini sehingga akan berdampak pada kesejaheraan masyarakat.
Tujuan dari pengabdian kepada

masyarakat ini adalah:

1. Membangun kebiasaan masyarakat untuk melakukan kegiatan-kegiatan dengan pemanfaatan lahan yang meskipun sempit sebagai kegiatan produktif bagi peningkatan kualitas hidup diri, keluarga dan masyarakat sekitarnya.

2. Memberdayakan masyarakat yang tidak produktif secara ekonomi menjadi masyarakat yang mandiri melalui pembudidayaan Jamur Tiram.

3. Menyediakan bahan pangan berupa jamur tiram yang dapat dikonsumsi oleh masyarakat setempat maupun masyarakat lainnya.

Secara garis besar manfaat kegiatan pengabdian ini adalah :

1. Membantu masyarakat untuk memiliki pengetahuan dan keterampilan yang dapat dikembangkan secara mandiri atau kelompok sebagai sistem mata pencaharian alternatif.

2. Meningkatkan perekonomian masyarakat yang mandiri melalui pembudidayaan Jamur Tiram yang bernilai ekonomi.

3. Menghasilkan bahan pangan berupa jamur tiram yang dapat dikonsumsi oleh masyarakat setempat maupun masyarakat lainnya.

Target dari kegiatan ini adalah semua masyarakat DesaDarek, Kecamatan Praya Barat Daya Kabupaten Lombok Tengah Provinsi Nusa Tenggara Barat. Masyarakat DesaDarek diharapkan mampu mandiri secara ekonomi menjadi masyarakat yang lebih sejahtera dan menjadi desa percontohan. adalah:

Luaran dari kegiatan pengabdian ini

(1) Menghasilkan bahan pangan berupa jamur tiram;

(2) Laporan Pengabdian.

\section{METODE PENGABDIAN}

PELAKSANAAN

Metode pelaksanaan pengabdian kepada masyarakat tentang pemberdayaan masyarakat melalui pembudidayaan jamur tiram dan pengolahan limbahnya menjadi pupuk organikakan dilaksanakan sebagai berikut. 


\section{Desk study dan Survey}

Hal-hal yang dilakukan adalah:

a) Desk study menelusuri dan mengevaluasi data sekunder dan study yang terkait

b) Melaksanakan survey data lapangan untuk memperoleh data lokasi dan kondisi sosial masyarakat secara mendetail

\section{Pelatihan dan Pendampingan pemberdayaan masyarakat}

Pelaksana pengabdian bersama mitra I tentunya akan membantu memberikan penyuluhan dan pelatihan kepada masyarakat. Selain itu, pelaksana pengabdian juga akan memfasilitasi masyarakat dengan mendatangkan tim pakar. Pelatihan dan pendampingan yang diberikan antara lain:

1. Penyuluhan cara membudidayan jamur tiram kepada masyarakat desa darek yang diwakili masing-masing oleh 5 orang dari 11 Dusun Pelatihan pembuatan pupuk organik

2. Pelatihan Pemasaran jamur tiram

\section{Pendampingan Pembudidayaan Jamur Tiram}

Adapun dalam pembudidayaan jamur tiram, ada beberapa tahapan yang harus diperhatikan oleh pembudidaya jamur tiram, yakni berupa persiapan media (substrat), pencampuran media, pengantongan, sterilisasi, inokulasi bibit, inkubasi, pemeliharaan tubuh bibit, dan panen.

1. Persiapan Media (Substrat), adapun media tanam untuk jamur tiram adalah sebai berikut: Serbuk gergajian kayu $=100 \mathrm{~kg}$, Dedak $=10 \mathrm{~kg}$, Kapur $=0,5 \mathrm{~kg}$, Tepung jagung $=0,5 \mathrm{~kg}$, Gula merah $=0,25 \mathrm{~kg}$, TSP $($ tambahan $)=0,25 \mathrm{~kg}$

2. Pencampuran Media Tanam: Bahan media tanam yang telah disiapkan diaduk sedemikian rupa (sehomogen) mungkin agar pertumbuhan miselium dapat merata ke seluruh media tanam. Kemudian pengadukan dapat dilakukan dengan cara mekanis maupun secara manual. Apabila dilakukan secara manual upayakan pengadukan lebih lama sehingga diperoleh pencampuran yang merata terutama untuk bahan bahan yang konsentrasinya rendah. Media yang telah tercampur dengan baik biasanya menggumpal pada saat dikepal. Bila proses pencampuran dilakukan pengomposan (fermentasi) selama 3-5 hari. Proses pengomposan dapat membantu untuk mengurangi kontaminasi oleh mikroba liar dan juga membantu penguraian beberapa senyawa kompleks untuk menjadi lebih sederhana sehingga lebih mudah diserap oleh jamur tiram. pengadukan dilakukan setiap hari dagan tujuan proses pengomposan merata.

3. Pengantongan atau pembuatan baglog dilakukan dengan memasukkan media yang telah dikompos ke dalam plastik tahan panas (polypropylene). Dan diupayakan pengisian tidak terlalu longgar dan juga padat. Untuk memadatkan media dapat dilakukan dengan bantuan botol yang diisi dengan pasir. Setelah diisi media pada bagian atas lalu diberi ring bambu, leher botol, gulungan kertas, dan bisa juga pipa dan di tutup dengan kapas sebagai sebagai sumbu dan sekaligus tempat memasukkan bibit atau tempat keluarnya jamur. setelah itu diikat dengan karet

4. Sterilisasi baglog melalui proses pasteurisasi dengan cara dikukus. Pasteurisasi yaitu proses pemanasan dengan suhu tidak lebih dari $100^{\circ} \mathrm{C}$ dengan waktu tidak kurang dari 5 jam. Pada umumnya para produsen melakukan pemanasan selama 8-12 jam. Pemanasan ini tergantung pada bahan dasar yang digunakan dan banyaknya log yang dipasteurisasi. Setelah selesai baglog didinginkan selama setengah sampai satu hari baru bisa digunakan.

5. Inokulasi bibit merupakan proses penanaman bibit ke dalam media tanam. Proses inokulasi dilakukan secara steril. ruangan diusahakan sebersih mungkin dan steril. Bila memungkinkan peralatan maupun ruangan disemprot alkohol terlebih dahulu. Selama proses ini disarankan menggunakan masker atau minimal tidak berbicara berlebihan untuk menghindari kontaminasi yang berasal dari uap mulut. Inokulasi dilakukan dengan memasukkan bibit (F2) sebanyak 2-5 sendok makan ke dalam lubang yang telah diberi cincin bamboo atau pipa atau 
bisa juga dengan menebarkannya di atas permukaan media hingga merata kemudian menutup kembali lubang ring bambu dengan kapas.

6. Inkubasi merupakan masa pertumbuhan miselium hingga memenuhi media secara merata. Suhu yang dibutuhkan pada proses ini yaitu antara $22^{\circ} \mathrm{C}-28^{\circ} \mathrm{C}$. diupayakan suhu ruangan inkubasi dijaga agar tetap stabil sehingga dapat menghasilkan pertumbuhan jamur yang optimum. inkubasi dilakukan selama kurang lebih 40 hari.

7. Pemeliharaan tubuh bibit. Pada masa pemeliharaan ini penutup baglog dibuka hingga seperempat bagian. Tahapan ini memerlukan suhu yang lebih rendah dibandingkan pada saat pertumbuhan miselium (tahap inkubasi) dan juga kelembapan yang optimum/berlimpah. Suhu yang diperlukan sekitar $20^{\circ} \mathrm{C}-26^{\circ} \mathrm{C}$ dengan kelembapan $80 \%-90 \%$. Pengaturan kelembapan dapat dilakukan dengan penyiraman sebanyak 2-3 kali setiap hari terutama ketika kelembapan di luar rendah biasanya pada saat siang hari. Selain kelembapan, kadar oksigen juga perlu diatur dengan membuka ventilasi ketika kelembapan di luar tinggi. Kelembapan perlu dikurangi hingga 70\%$80 \%$ apabila tubuh bibit telah mencapai ukuran dewasa. Hal ini dilakukan untuk menghindari tekstur tubuh bibit tidak lembek yang bisa menyebabkan tidak tahan lama atau cepat busuk.

8. Panen dilakukan setelah 7-10 hari penutup dibuka, tubuh bibit biasanya sudah mulai tumbuh. Selang 3-4 hari setelah tunas tubuh bibit tumbuh, menunjukkan jamur telah siap dipanen. Pemanenan harus dilakukan dengan hati-hati dengan cara mencabut seluruh rumpun tubuh bibit jamur yang ada beserta akarnya. Karena akar yang tertinggal bisa menyebabkan pertumbuhan tubuh bibit selanjutnya terganggu karena terjadi pembusukan media. Panen sebaiknya dilakukan pada pagi atau sore hari pada saat jamur masih dalam kondisi segar. Panen kedua biasanya berlangsung dalam rentang waktu 1-2 minggu setelah panen pertama.
Usia produktif berlangsung 3-4 bulan dengan produksi satu baglog sekitar 0,6 kg. Setelah dilakukan pemanenan, log dipelihara seperti awal penanaman yaitu dengan melakukan penyiraman, pengaturan suhu, kelembapan serta aerasi

Sebagai masyarakat pemula atau pengusaha skala kecil sementara waktu bibit ataupun media tanam dibeli dari Mitra 1. Proses pembudidayaan jamur tiram dilaksakan secara bersama oleh semua anggota koperasi. Langkah awal yang dilakukan adalah

1. Pembangunan kumbung pembudidayaan jamur tiram secara bersama semua anggota

2. Pembelian baglog ( Mitra 1 sebagai Suplayer)

3. Pembudidayaan jamur.

Kegiatan pengabdian ini dilaksanakan pada pada tanggal 25 Maret 2019

\section{HASIL YANG DICAPAI HASIL DESK STUDY}

\section{Setelah pengumuman proposal penelitian dan pengabdian kepada masyarakat, dan proposal ini dinyatakan diterima, maka yang pertama kali dilakukan adalah desk study. Desk study dilaksanakan dengan menelusuri dan mengevaluasi data sekunder dan study yang terkait. Kegiatan desk study dimulai dengan pencarian literature untuk melenglapi teori dan data lainnya yang belum lengkap pada proposal.Setelah itu, perbaikan proposal dilaksanakan.Hasilnya adalah proposal edisi revisi.}

\section{HASIL SURVEY}

Survey lapangan dilaksanakan untuk memperoleh data lokasi dan kondisi sosial masyarakat secara mendetail.Survey ini dilaksanakan di DesaDarek Kecamatan Praya Barat Daya pada tanggal 01 Maret 2019 untuk mendapatkan informasi secara mendalam dan mendetil tentang kondisi masyarakat sekitar. Kegiatan ini dilaksanakan dengan melaksanakan pengamatan di DesaDarek Kecamatan Praya Barat Daya dan melaksanakan diskusi dengan beberapa masyarakat yang ditemui. Dari hasil pengamatan dan diskusi, diperoleh informasi bahwa di desa darek banyak masyarakat yang 
bekerja sebagai tukang bangunan khususnya pembuat kusen sehingga di desa darek ini banyak terdapat serbuk kayu yang tidak dimanfaatkan oleh warga. Di desa darek juga terdapat dua buah heler sehingga dsangat mudah sekali untuk mendapatkan dedak yang merupakan bahan dasar pembuatan baglog jamur tiram. Hasil dari kegiatan survey ini menyepakati akan diadakan kegiatan sosialisasi kegiatan pengabdian kepada masyarakat dengan tema "Pemberdayaan Masyarakat melalui Budidaya Jamur Tiram" yang dilaksanakan pada tanggal 30-31 Maret 2019

Berdasarkan hasil sosialisasi diperoleh kesepakan bahwa kegiatan pengabdian dilaksanakan di Desa Darek Kecamatan Praya Barat Daya bertempat di kantor desa Darek. Kepala Desa, Kepala Dusun, Ketua RT, dan perwakilan masyarakat merasa senang dan siap mendukung pelaksanaan kegiatan pengabdian bagi masyarakat.

\section{HASIL PELATIHAN DAN}

\section{PENDAMPINGAN}

Pelaksanaan pelatihan dan pendampingan dilaksanakan secara berkala. Setiap pelatihan juga mendatangkan narasumber yang ahli dibidang kajian sesui materi pelatihan. Ada beberapa pelatihan dan pendampingan yang dilaksanakan.

1. Sosialisassi Budidaya Jamur Tiram

Kegiatan ini dilaksanakan pada hari Sabtu tanggal 30 Maret2019 dengan tujuan untuk membuka wawasan masyarakat desa Darek tentang budidaya Jamur Tiram. Materi disampaikan oleh narasumber yang sudah berpengalaman dalam pembudidayaan jamur tiram yaitu bapak Ismail Efendi, M.Pd. Materi yang disampaikan meliputi peluang ekonomi dan teknik budidaya jamur tiram.

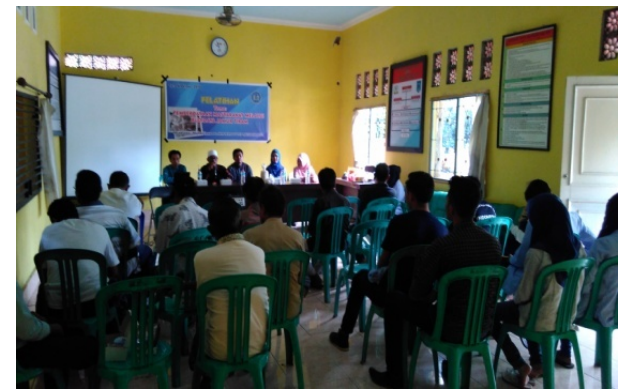

Gb 1. Sosialisai Kegiatan Pengabdian yang dibuka oleh Kepala Desa Darek

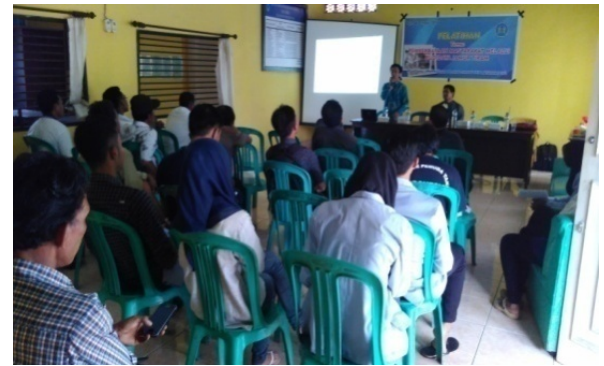

$\mathrm{Gb}$ 2. Penyampaian materi pelatihan yang disampaikan oleh bapak Ismail Efendi, M.Pd

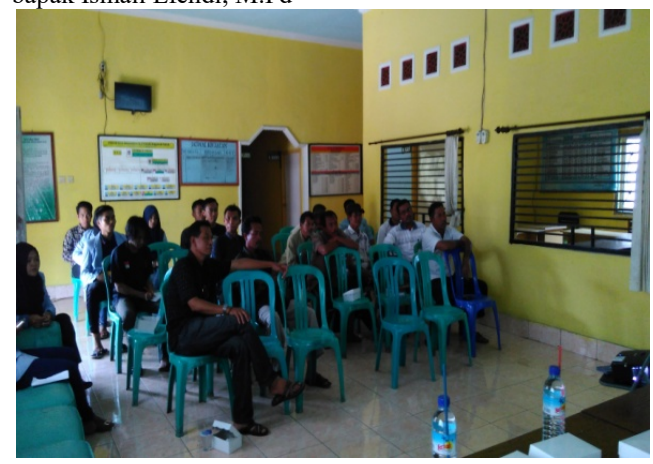

$\mathrm{Gb}$ 3. Warga Antusias mendengarkan penjelasan sosialisai Kegiatan Pengabdian

\section{Pelatihan pembuatan baglog}

Setelah selesai penyampaian materi tentang pelatihan budidaya jamur tiram, dilanjutkan dengan pelatihan pembuatan baglog.Pelatihan ini diikuti oleh seluruh peserta dan dalam pelaksanaannya dipandu olehMahsar yaitu mahasiswa Pendidikan Biologi yang telah melaksanakan penelitian tentang jamur tiram dibantu oleh mahasiswa KKN yang ada di Desa Darek.Proses pembuatan baglog menghasilkan 50 baglog dengan ukuran baglog yang dibuat adalah 2 $\mathrm{kg}$.

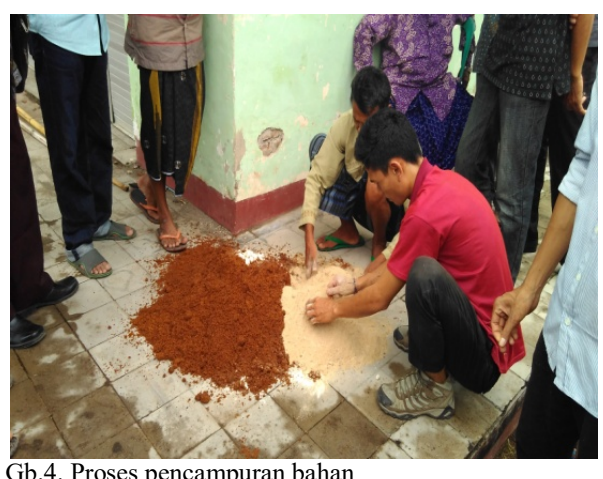

Gb.4. Proses pencampuran bahan 

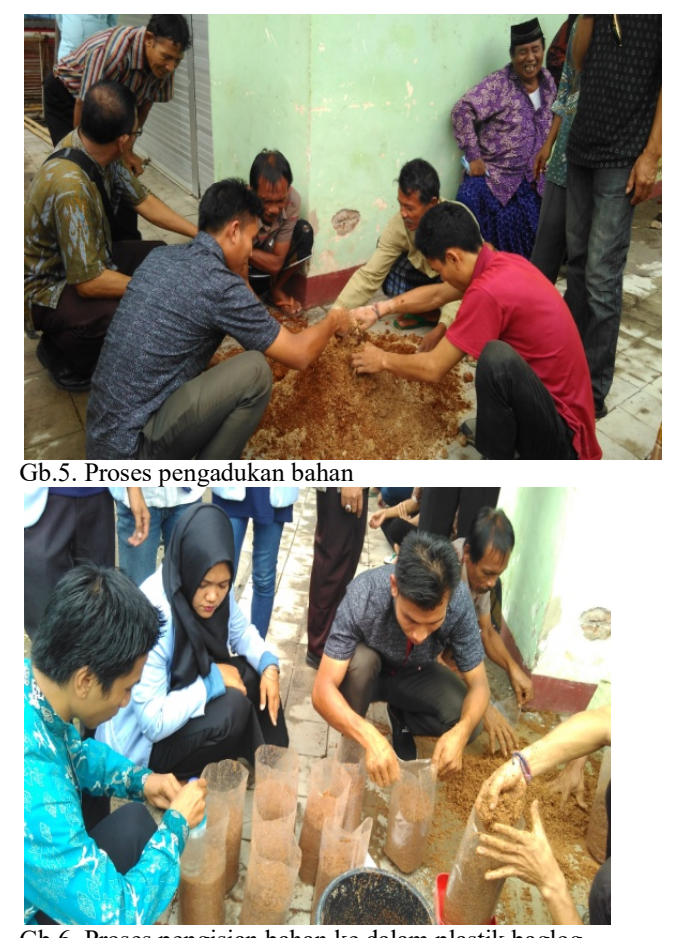

Gb.6. Proses pengisian bahan ke dalam plastik baglog

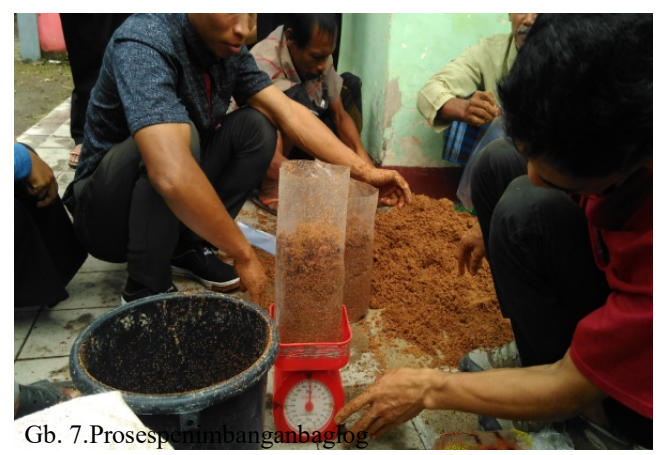

3. Pelatihan inokulasi

Sebelum dilakukan inokulasi, terlebih dahulu dilakukan sterilisasi baglog melalui proses pasteurisasi dengan cara dikukus.selama 8-12 jam. Proses inokulasi dilakukan secara steril. Ruangan diusahakan sebersih mungkin dan steril. Bila memungkinkan peralatan maupun ruangan disemprot alkohol terlebih dahulu. Selama proses ini disarankan menggunakan masker atau minimal tidak berbicara berlebihan untuk menghindari kontaminasi yang berasal dari uap mulut. Inokulasi dilakukan dengan memasukkan bibit (F2) sebanyak 2-5 sendok makan ke dalam lubang yang telah diberi cincin pipa atau bisa juga dengan menebarkannya di atas permukaan media hingga merata kemudian menutup kembali lubang ring bambu dengan kapas.
Setelah dilakukan proses inokulasi maka baglog siap untuk diinkubasi yaitu masa pertumbuhan miselium hingga memenuhi media secara merata. Suhu yang dibutuhkan pada proses ini yaitu antara $22^{\circ} \mathrm{C}-28^{\circ} \mathrm{C}$. diupayakan suhu ruangan inkubasi dijaga agar tetap stabil sehingga dapat menghasilkan pertumbuhan jamur yang optimum. inkubasi dilakukan selama kurang lebih 40 hari
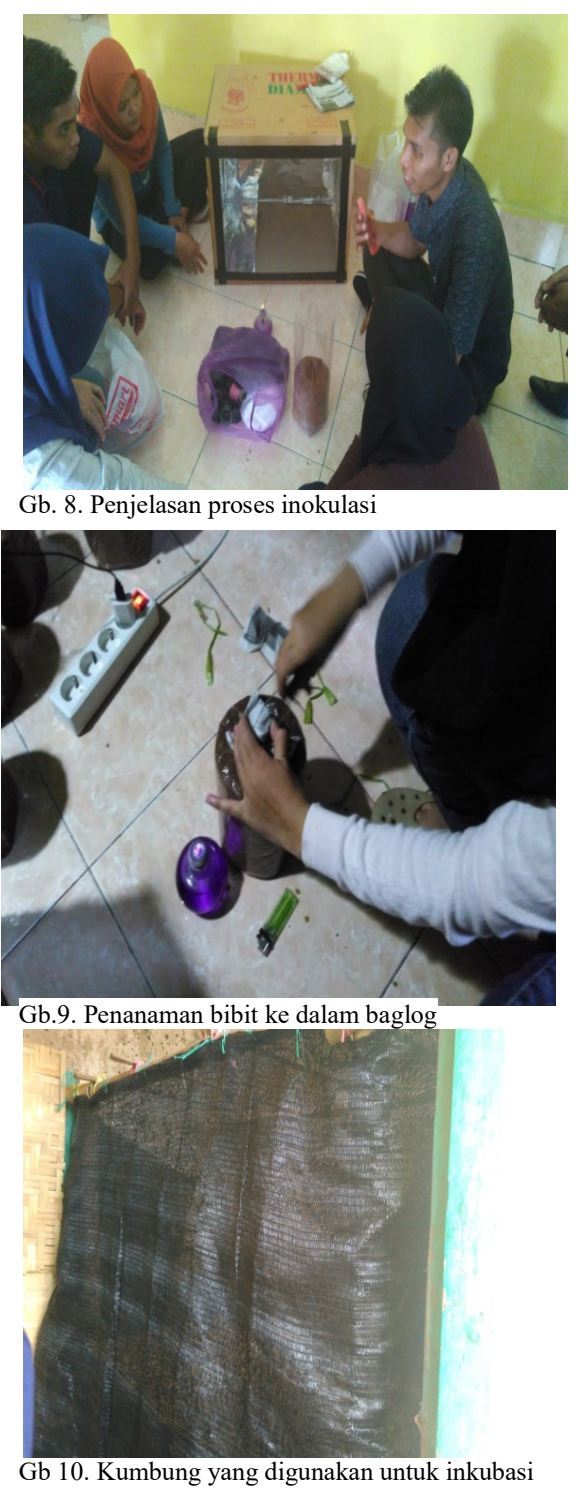

\section{SIMPULAN}

Berdasarkan hasil pelaksanaan kegiatan yang dilaksanakan maka dapat disimpulkan: Pelaksanaan kegiatan pengabdian ini berjalan dengan baik. Luaran yangyang dihasilkan yaitu: 
a. Menghasilkan bahan pangan berupa jamur tiram;

b. Laporan Pengabdian.

\section{SARAN}

1. Keterlibatan masyarakat belum maksimal oleh karena itu kepada masyarakat agar lebih berperan aktif dalam mengajak warga dalam mengembangkan usaha budidaya jamur tiram.

2. Pelatihan ini hanya menghasilkan jamur tiram saja sehingga perlu diadakan pelatihan pengolahan hasil panen jamur sehingga menghasilkan nilai ekonomi yang lebih tinggi.

3. Agar hasil panen lebih maksimal maka diperlukan lahan untuk membuat kumbung yang lebih besar sehingga dapat menampung baglog lebih banyak.

\section{DAFTAR PUSTAKA}

Efendi, Ismail. 2012. Pembudidayaan Jamur Tiram.Mataram: Jakamandala

Istiarti, V.G Tinuk, Priyadi N, Laksmono W, Emmy R. 2009. Pemberdayaan Masyarakat. Semarang: Undip Press.

Masjudin. 2011. Membangun Koperasi Syariah.

http://www.blogasjudinpemberdayaan.c om/pemberdayaan/pemberdayaanmasyarakat-adat-dantantangannya.html. Diakses pada tanggal 23 April 2012.

Purnomo, H \& Adition. 1985. Ilmu Pangan (Terjemahan). Jakarta: UI Press.

Winarno, F.G. 1980. Kimia Pangan. Bogor. Pusbangtepa-FTDC IPB 